\title{
Key factors for defining an efficient urban transport interchange: users' perceptions
}

\author{
Sara Hernández, Andrés Monzon
}

\begin{abstract}
The sustained increase in the urban population and the trend towards urban sprawl in European cities has led to a change in mobility patterns, and many public transport users now need to combine several modes or transport services at urban transport interchanges before they reach their final destination. Therefore, they have become an everyday experience for users where, in addition, users spend time inside. This paper aims to identify the key factors both from a functional and psychological perspective for defining an efficient transport interchange. Since the users' perceptions of their experience are particularly important for achieving the most appropriate policy measures for interchanges, an ad-hoc travellers' satisfaction survey was designed and carried out in three European transport interchanges. The assessment methodology used here -Principal Component Analysis- is proposed as a useful step-by-step procedure. The results of this research highlight the ambivalent nature of the urban transport interchanges. The key functional aspects identified contribute to make easier the transfer and reduce the waiting time, while the psychological factors make the stay more comfortable for users.
\end{abstract}

Key words: transport interchanges, urban mobility, users' perceptions, intermodal transfer, Principal Component Analysis

\section{Highlights:}

- Urban transport interchanges are vital elements for reducing transfer inconvenience

- A travellers' satisfaction survey was done to capture users' perceptions

- Principal Component Analysis is used to identify the main factors for users

- Travellers make decisions based on perceived walking and waiting times

- The overall interchange performance is directly linked to safety and security conditions

\section{Introduction}

Cities worldwide are undergoing clear and continuous growth. More than half the world's population today lives in urban areas, and this trend is expected to continue rising. According to Heilig (2012), by 2050, 86\% of the global population in developed regions will live in urban areas. Cities today are complex systems, with massive numbers of interconnected citizens, businesses, transport modes, services and utilities (Neirotti, De Marco, Cagliano, Mangano, \& Scorrano, 2014).

This sustained increase in the urban population and the trend towards urban sprawl in European cities has led to a shift in mobility patterns. The challenge facing all major cities is how to increase mobility while at the same time reducing congestion, accidents and 
pollution (COM, 2006). This rapid growth has gone hand in hand with greater demand for transportation facilities (Debnath, Chin, Haque, \& Yuen, 2014). In urban areas -the scenario of most daily trips-, distances travelled and travel times have risen dramatically (Banister, 2011), forcing many public transport users to combine different transport modes to complete their trips and decreasing the attractiveness of public transport versus the private car. Reducing the inconvenience inherent in transferring between modes is a basic principle for achieving sustainable mobility.

The Committee on Intermodal Transfer Facilities, Transportation Research Board (1974), already pointed out that the total effectiveness of the transportation network is determined by intermodal transfer facilities. Iseki \& Taylor (2009) noted that the attractiveness of Public Transport (PT) can be substantially increased by reducing the burden of walking, waiting and transferring. It is therefore crucial to establish the factors that optimize and determine the competitiveness of these terminals. At the urban level, transport interchanges are vital to ensuring smooth journeys for passengers and improving the overall efficiency of the public transport system (Abreu e Silva \& Bazrafshan, 2013; Li, 2013). As defined by Edwards (2011), a transport interchange is a more complex transport facility than a conventional station, and allows travellers to transfer from one mode to another. Intermodal transfers are more onerous than intramodal transfers (Liu, Pendyala, \& Polzin, 1997). Urban transport interchanges are located within cities and play a key role both as transport network nodes and as 'meeting places', thereby enhancing their function as a place and not as a barrier, and creating synergies unrelated to transport. Peek \& van Hagen (2002) noted that this ambivalent nature creates opportunities for synergy between both functions: moving and staying. This dual approach can also be compared with the new concept of High Speed Rail stations within cities defined by Bertolini \& Spit (1998).

As noted by Terzis \& Last (2000), an efficient urban transport interchange must be competitive and, at the same time, be attractive for users given that their physical experiences and psychological reactions are significantly influenced by the design and operation of the interchange. Therefore, the main goal of this paper is to identify the key factors from the users' point of view that define an efficient urban transport interchange, i.e seeking balance of this dual approach: functional and psychological. This was done by conducting a travellers' satisfaction survey in three European transport interchanges.

The paper is structured as follows. Section 2 presents the review of the literature into the key aspects and elements identified as important in the design, operation and management of multimodal passenger transport stations. Section 3 defines the main features of each case study. The data collection procedure and assessment methodology are described in sections 4.1 and 4.2 respectively. The analysis of the key factors obtained and the interpretation of the results are presented in section 5. Finally, section 6 summarizes the main conclusions and offers some essential principles for defining an efficient urban transport interchange.

\section{Multimodal transport stations: review of previous studies}

Transport interchanges today are a crucial element in sustainable urban transport policies (COM, 2007), and yet there are no standards or regulations specifying the form 
these interchanges should take in Europe. In fact, the literature review reveals that most studies and research focus mainly on railway and underground stations. This section reviews the studies that identify the key aspects and elements for defining, operating and managing multimodal transport stations, and the most recent studies on the subject of urban transport interchanges.

A survey carried out in the United States and Canada identified covered waiting areas and passenger information as the most common amenities provided at transfer facilities (Stern, 1996). This study analysed these facilities as transport nodes within a network, but disregarded other aspects. Desiderio (2004) pointed out that in urban environments, multimodal transport stations also establish relationships between users and the territory, and should thus be considered as an element in urban development strategies, due to their role as "city gates". They should generally be considered as multimodal facilities where travellers are not only passing through, but are also spending time (van Hagen, 2011). It is therefore crucial to take into consideration other aspects and elements that improve the users' experience.

The Station User Panel (2011) developed seven 'Railway Station Usability Principles' for the government of Victoria (Australia) in order to improve railway station effectiveness taking into consideration the users' experience of the rail system. These principles were: accessibility, ease of navigation, comfort \& amenities, information, safety, local area integration and community ownership \& activity. Peek \& van Hagen (2002) also identified safety and comfort as important requisites in railway station operation. However, visual features such as layout and visible presence of staff were identified as key aspects for improving stations from the 'meeting place' perspective (Peek \& van Hagen, 2002). Garmendia, Ribalaygua, \& Ureña (2012) concluded that the 'station as a place' approach produced different outcomes, usually depending on the size of the city. Durmisevic \& Sariyildiz (2001) focused their research on analysing various techniques for building underground stations and examined their efficiency, again taking into account the human factor. This study defined important 'functional aspects' for the operation of the station internal connections of the spaces and efficiency of movement- and 'psychological aspects' such as public safety and comfort- that are more closely related to the user's experience of a station as a space.

Terzis \& Last (2000) carried out one of the first research works into the subject of urban transport interchanges. This study concluded that accessibility, facilities, image and information provision were the most relevant aspects in the design and operation of interchanges. Desiderio (2004) focused on analysing the factors that determine the quality of intermodal interchanges considering both users' and operators' requirements. These factors were classified into six different categories: accessibility \& external circulation, physical design, shops \& amenities, security \& psychological factors, information and ticketing.

The latest research on urban transport interchanges found that these multimodal facilities also depend on other factors such as the position in the network, the urban environment and the modes involved (Harmer et al., 2014). Hernandez, Monzon, \& De Oña (2015) proposed a methodological framework to identify the strengths and weaknesses of transport interchanges. The results showed information, transfer conditions and safety \& security to be the most relevant aspects. 
In summary, the literature review essentially reveals there are two types of aspects to take into consideration in the design, operation and management of passenger multimodal transport stations, and particularly in railway and underground stations. Most studies identify information provision and accessibility as the most relevant functional features, while safety \& security and comfort as the most important psychological aspects. The other relevant aspects identified are listed below:

- Layout

- Internal connections

- Ease of movement

- Waiting areas

- Services and facilities

But, how should an existing or new urban transport interchange perform? Which fundamental functional and psychological aspects are fundamental from the users' point of view? This study aims to identify the key factors and provide essential principles for reducing the transfer inconvenience and thus, improving the user's experience at urban transport interchanges.

\section{Description of the case studies}

According to Pitsiava-Latinopoulou \& Iordanopoulos (2012), the location, the transport modes involved and the passengers' characteristics are key variables for determining the category of a multimodal transport station. European case studies were therefore selected to provide a balance in terms of geography, seeking a heterogeneous range of transport modes, size and the role of the interchange within the city in order to evaluate different types of the interchanges. Additionally, the typology was selected following the classification criteria developed by PORTAL (2003) that defined the transport interchanges according to their location in the network: peripheral interchanges, sub-centre interchanges and city centre interchanges, respectively. The interchanges selected were Ilford Railway Station (London, UK), Moncloa (Madrid, Spain) and Kamppi (Helsinki, Finland). Table 1 provides a brief description of the main features of each interchange. Additionally, it shows the transport modes involved at each case study and indicates the daily demand of the main modes in each transport interchange.

Kamppi and Moncloa are fairly new urban interchanges, built and refurbished in 2006 and 2008 respectively. Conversely, Ilford was built in 1839 and rebuilt in 1980. The transport modes and services involved in the interchanges vary. Users travel mainly by metro and bus in Kamppi and Moncloa, and by rail in Ilford. The role of the Moncloa interchange is basically local and regional with only a few national services, while the Kamppi interchange also includes the main national bus station. There is also one international bus service (i.e. to St. Petersburg). The Ilford interchange is predominantly a railway station and focuses on local services, mainly for local commuter trips. 
Table 1: Main characteristics of the case studies

\begin{tabular}{|c|c|c|c|c|c|}
\hline $\begin{array}{l}\text { Urban } \\
\text { transport } \\
\text { interchange }\end{array}$ & Year built & Modes of transport (1) & $\begin{array}{r}\text { Passengers/day } \\
\text { (2013) }\end{array}$ & Role/place & $\begin{array}{l}\text { Description } \\
\text { surrounding }\end{array}$ \\
\hline $\begin{array}{l}\text { Ilford } \\
\text { Railway } \\
\text { Station }\end{array}$ & $\begin{array}{l}1839 \\
\text { Rebuilt in } \\
1980 \\
\text { Planned for } \\
\text { refurbishment }\end{array}$ & $\begin{array}{l}\text { Rail } \\
\text { Bus } \\
\text { Bike (with bike parking) } \\
\text { Private car with drop off } \\
\text { Car parking } \\
\text { Taxi }\end{array}$ & 22,405 & $\begin{array}{l}\text { Local + } \\
\text { Regional }\end{array}$ & $\begin{array}{l}\text { Large suburban town } \\
\text { in the London } \\
\text { borough of } \\
\text { Redbridge. Located in } \\
\text { the town centre. } \\
\text { Shopping centre } \\
\text { opposite the station. } \\
\text { (Peripheral } \\
\text { interchange) }\end{array}$ \\
\hline Moncloa & $\begin{array}{l}1995 \\
\text { Refurbishment } \\
\text { in } 2008\end{array}$ & $\begin{array}{l}56 \text { metropolitan bus } \\
\text { lines } \\
3 \text { urban bus lines } \\
2 \text { metro lines } \\
2 \text { long distance bus lines } \\
\text { No private car parking }\end{array}$ & $\begin{array}{r}59,989 \\
96,789 \\
109,321\end{array}$ & $\begin{array}{l}\text { Local + } \\
\text { Regional + } \\
\text { National } \\
\text { (2 lines) }\end{array}$ & $\begin{array}{l}\text { Entrance gateway to } \\
\text { Madrid, near city centre } \\
\text { and area with historic } \\
\text { monuments. Metroline } 6 \\
\text { connects all central } \\
\text { points in Madrid } \\
\text { (Sub-centre } \\
\text { interchange) }\end{array}$ \\
\hline Kamppi & $\begin{array}{l}2005 \\
\text { (Started } \\
\text { operation) } \\
2006 \\
\text { (Shopping } \\
\text { centre) }\end{array}$ & $\begin{array}{l}21 \text { local bus lines } \\
40 \text { regional bus lines } \\
\mathbf{1 5} \text { metropolitan bus } \\
\text { lines } \\
\mathbf{1} \text { metro line } \\
1 \text { international bus line } \\
2 \text { tram lines on street } \\
\text { network } \\
\text { Bike centre (parking, } \\
\text { rental, service) } \\
\text { Car parking } \\
\text { Taxis }\end{array}$ & $\begin{array}{r}19,360 \\
8,500 \\
7,500 \\
21,700\end{array}$ & $\begin{array}{l}\text { Local + } \\
\text { Regional + } \\
\text { National + } \\
\text { International } \\
\text { (1 bus to St. } \\
\text { Petersburg) }\end{array}$ & $\begin{array}{l}\text { Central location in } \\
\text { downtown Helsinki. } \\
\text { Shopping centre. } \\
\text { Railway station is } 500 \\
\text { metres from the } \\
\text { Kamppi interchange. } \\
\text { (City centre } \\
\text { interchange) }\end{array}$ \\
\hline
\end{tabular}

(1) The most relevant transport modes in each case study and their daily demand are indicated in bold

It is worth noting that all three interchanges play a key role in multimodal trips in their corresponding cities and cover a wide spectrum of interchange types and geographical distributions.

\section{Methodological framework assessment}

The above review highlights several points that are relevant to travellers' decisionmaking, and particularly that they find transfers to be stressful and/or time-consuming, thus discouraging PT use (Iseki \& Taylor, 2009). It is therefore essential to determine which attributes and factors define an efficient urban transport interchange from the users' point of view. This section presents the data collected in each case study in order to capture the users' views, along with the targeted analytical methodology that was applied to obtain these factors, thus enabling its effective implementation by policy planners and operators.

\subsection{Data collection through a travellers' satisfaction survey}

Passenger multimodal transport facilities tend to be designed and operated by multiple stakeholders. However several authors conclude that an understanding of the users' views is essential for defining and developing an efficient urban transport interchange 
(Durmisevic \& Sariyildiz, 2001; Peek \& van Hagen, 2002; Friman, 2010; Harmer et al., 2014) A travellers' satisfaction survey was designed and implemented in the three case studies described above. This ad-hoc survey contained primarily 37 observed variables relating to different aspects and elements of an interchange (see Figure 1), based on the findings of the literature review and previous studies (PIRATE, 1999; Terzis \& Last, 2000; Durmisevic \& Sariyildiz, 2001; Iseki \& Taylor, 2010; Abreu e Silva \& Bazrafshan, 2013) and built to consider the following eight categories: 1) travel information, 2) way-finding information, 3) time \& movement, 4) access, 5) comfort \& convenience, 6) image \& attractiveness, 7) safety \& security, and 8) emergency situations. Each respondent was asked to rate the level of satisfaction with each of the 37 variables on a Likert scale from 1 (strongly dissatisfied) to 5 (strongly satisfied). The 5-point Likert scale was adopted because it is the most widely adopted in the traveller's satisfaction questionnaires (De Oña, 2013). Additionally, the survey also contained some questions related to socio-economic characteristics and trip habits in order to define user profiles and mobility patterns.

A new implementation method was applied to do the survey in urban transport interchanges combining computer-assisted methods (online surveys) with traditional techniques (face-to-face interviews). Firstly, a short face-to-face interview was conducted to travellers in order to explain them the main objectives of the survey and secondly, they were given a card which included a link to the survey website and a survey number to monitor the received surveys and avoid duplication of responses. They were carried out between May 2013 and October 2013. They were received 1,471 surveys $\left(\mathrm{N}_{\text {Ilford }}=234\right.$, $\mathrm{N}_{\text {Moncloa }}=928$ and $\mathrm{N}_{\text {Kamppi }}=309$ ) and by ruling out any incomplete or incorrectly answered surveys, there was a total sample of 1,389 valid surveys $\left(\mathrm{N}_{\text {Ilford }}=226, \mathrm{~N}_{\text {Moncloa }}=865\right.$ and $\mathrm{N}_{\text {Kamppi }}=$ 298). 


\section{OBSERVED VARIABLES}

1. Availability and clarity of travel information at the interchange

2. Availability of travel information before your trip

3. Accuracy and reliability of travel information displays

4. Ease ticket purchasing

5. Signposting of different facilities and services

6. Signposting for transfers between transport modes

7. Information and assistance provided by staff

\section{Transfer distances}

9. Coordination between operators or transport services

10. Time use at the interchange

11. Distance between the facilities and services

12. Number of elevators, escalators and moving walkways

13. Ease of movement inside the interchange due crowding 14. Ease of access to the interchange

15. General cleanliness of the interchange

16. Temperature, shelter, ventilation

17. General noise level in the interchange

18. Air quality and pollution

19. Number and variety of shops

20. Number and variety of cafés and restaurants

21. Availability of cash machines

22. Availability of seating

23. Availability of telephone signals and Wi-Fi

24. Comfort due to presence of information screens

25. Area surrounding the interchange

26. Internal design of the interchange

27. External design of the interchange

\section{Safety getting on and off transport}

29. Safety inside the interchange

30. Feeling secure in the transfer and waiting areas (during the day)

31. Feeling secure in the transfer and waiting areas (evening/night)

32. Feeling secure in the area surrounding the interchange

33. Lighting

34. Real time information to improve sense of security

35. Signposting of emergency exits

36. Location of escalators in the event of an emergency

37. Location of exits in the event of an emergency

\section{CATEGORIES}

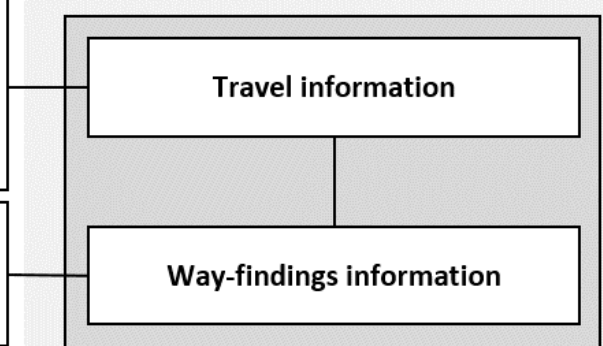


Table 2: Main characteristics of the user profiles and trip patterns for each case study

\begin{tabular}{|c|c|c|c|c|c|}
\hline & \multirow[b]{2}{*}{ Moncloa } & \multirow[b]{2}{*}{ Kamppi } & \multirow[b]{2}{*}{$\begin{array}{r}\text { Ilford Railway } \\
\text { Station } \\
\end{array}$} \\
\hline & & & & & \\
\hline \multirow{11}{*}{ 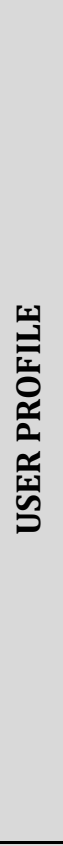 } & \multirow{2}{*}{ Gender } & Female & $54.1 \%$ & $64.1 \%$ & $39.3 \%$ \\
\hline & & Male & $45.9 \%$ & $35.9 \%$ & $60.7 \%$ \\
\hline & \multirow{3}{*}{ Age } & $(18-25)$ & $42.5 \%$ & $14.5 \%$ & $8.0 \%$ \\
\hline & & $(26-40)$ & $26.1 \%$ & $33.8 \%$ & $42.4 \%$ \\
\hline & & $(41-65)$ & $28.0 \%$ & $44.3 \%$ & $42.0 \%$ \\
\hline & \multirow{2}{*}{$\begin{array}{l}\text { Employment } \\
\text { status }\end{array}$} & Employee & $49.0 \%$ & $71.8 \%$ & $83.1 \%$ \\
\hline & & Student & $38.0 \%$ & $16.1 \%$ & $4.9 \%$ \\
\hline & $\begin{array}{l}\text { Frequency of } \\
\text { use of the } \\
\text { interchange } \\
\text { (1) }\end{array}$ & Habitual user* & $84.7 \%$ & $62.4 \%$ & $80.5 \%$ \\
\hline & PT ticket & Monthly pass & $84.5 \%$ & $61.7 \%$ & $65.5 \%$ \\
\hline & Driving license & Yes & $70.9 \%$ & $75.8 \%$ & $66.8 \%$ \\
\hline & $\begin{array}{l}\text { Access to } \\
\text { private vehicle }\end{array}$ & No & $62.0 \%$ & $36.9 \%$ & $43.4 \%$ \\
\hline \multirow{21}{*}{ 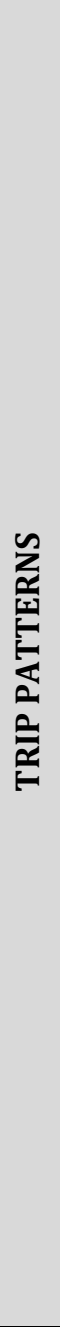 } & & Starting & $34.9 \%$ & $38.6 \%$ & $72.1 \%$ \\
\hline & Journey stage & Transfer & $56.9 \%$ & $36.9 \%$ & $11.6 \%$ \\
\hline & & Ending & $8.2 \%$ & $24.5 \%$ & $16.0 \%$ \\
\hline & $\begin{array}{l}\text { Number of } \\
\text { transfers } \\
\text { (mean) }\end{array}$ & --- & 2.0 & 1.0 & 2.0 \\
\hline & \multirow{8}{*}{$\begin{array}{l}\text { Main egress } \\
\text { mode }\end{array}$} & Train & --- & --- & $28.4 \%$ \\
\hline & & Metro & $51.9 \%$ & $25.2 \%$ & --- \\
\hline & & Metropolitan bus & $23.7 \%$ & $46.3 \%$ & $28.9 \%$ \\
\hline & & Walking & $10.4 \%$ & $18.5 \%$ & $37.8 \%$ \\
\hline & & Train & --- & --- & $64.4 \%$ \\
\hline & & Metro & $17.5 \%$ & $21.5 \%$ & --- \\
\hline & & Metropolitan bus & $58.8 \%$ & $50.3 \%$ & $8.0 \%$ \\
\hline & & Walking & $8.9 \%$ & $22.8 \%$ & $24.0 \%$ \\
\hline & \multirow{3}{*}{ Trip purpose } & Work & $48.6 \%$ & $55.4 \%$ & $81.4 \%$ \\
\hline & & Study & $34.5 \%$ & $10.7 \%$ & $3.1 \%$ \\
\hline & & Leisure & $11.1 \%$ & $30.5 \%$ & $12.4 \%$ \\
\hline & $\begin{array}{l}\text { Total travel } \\
\text { time (median) }\end{array}$ & --- & $50 \mathrm{~min}$ & $45 \min$ & $45 \mathrm{~min}$ \\
\hline & $\begin{array}{l}\text { Time inside } \\
\text { the } \\
\text { interchange } \\
\text { (median) }\end{array}$ & -- & $10 \mathrm{~min}$ & $9 \min$ & $6 \mathrm{~min}$ \\
\hline & \multirow{4}{*}{$\begin{array}{l}\text { Use of time } \\
\text { (inside the } \\
\text { interchange) }\end{array}$} & Transferring & $18.2 \%$ & $17.6 \%$ & $39.1 \%$ \\
\hline & & Queuing & $58.3 \%$ & $39.4 \%$ & $38.5 \%$ \\
\hline & & Shopping & $6.8 \%$ & $25.2 \%$ & $4.6 \%$ \\
\hline & & Other pursuits & $16.7 \%$ & $17.8 \%$ & $17.8 \%$ \\
\hline
\end{tabular}

(1) Habitual user: user who uses the interchange daily or 3-4 times a week 


\subsection{Principal Component Analysis: step-by-step procedure}

The methodology applied in this study is based on a Principal Component Analysis (PCA) covering the set of 37 observed variables described in section 4.1. This analysis is a complex multi-step process that aims to identify groups or clusters of variables. These clusters help reduce a dataset to a more manageable size in order to understand and interpret the structure of the set of variables (Field, 2009). This statistical technique has been widely used and broadly applied in social sciences (Costello \& Osborne, 2005).

Several aspects and conditions must be considered to ensure the correct application of this analytical technique. A step-by-step procedure is proposed in view of the nature of the data and the study objective, based on previous research on the urban built environment (Comendador, López-Lambas, \& Monzon, 2014). The PCA were applied to the three samples obtained in each case study and performed using the SPSS®v20 software package

\section{Step 1. Data consistency}

A number of conditions must be checked previously to ensure the correct application of the PCA as shown in Table 3. Bartlett's test showed highly significant results in all cases, indicating that correlations among the 37 observed variables are sufficiently large to apply a PCA. Excellent results were also obtained for both the KMO index and the reliability of the sample.

Table 3: Statistical criteria to be met before a Principal Component Analysis

\begin{tabular}{|c|c|c|c|}
\hline & $\begin{array}{l}\text { Ilford Railway Station } \\
\left(\mathrm{N}_{\text {Ilford }}=226\right)\end{array}$ & $\begin{array}{l}\text { Moncloa }^{\mathrm{a}} \\
\left(\mathrm{N}_{\text {Moncloa }}=865\right)\end{array}$ & $\begin{array}{l}\text { Kamppi } \\
\left(\mathrm{N}_{\mathrm{Kamppi}}=298\right)\end{array}$ \\
\hline \multirow{2}{*}{ Sample size (1) } & $>200$ & $>500$ & $\approx 300$ \\
\hline & Fair & Very good & Good \\
\hline \multirow{2}{*}{ Reliability (2) } & 0.967 & 0.948 & 0.953 \\
\hline & Excellent & Excellent & Excellent \\
\hline \multirow{2}{*}{ KMO index (3) } & 0.948 & 0.950 & 0.937 \\
\hline & Superb range & Superb range & Superb range \\
\hline Bartlett's test sphericity & $\mathrm{p}<0.000$ & $\mathrm{p}<0.000$ & $\mathrm{p}<0.000$ \\
\hline (Jackson, 1993) & $\operatorname{chi}^{2}(630)=6,354.300$ & $\operatorname{chi}^{2}(630)=15,995.266$ & $\operatorname{chi}^{2}(666)=6,544.268$ \\
\hline
\end{tabular}

a Item 12 in the Moncloa transport interchange was excluded from the PCA as it had a loading of less than 0.3 in all factors, and its communality was less than 0.4, meaning that this variable was not properly classified in any factor extracted. The PCA was re-applied to the 36 variables.

(1) There are many 'rules of thumb' about the proper sample size. The common rule is to have at least 10-15 participants per observed variable (Field, 2009). Nevertheless, Comrey \& Lee (1992) defined the following ranges: 100 as poor, 200 as fair, 300 as good, 500 as very good, and 1000 or more excellent. (2) Cronbach's alpha is the measure of internal consistency reliability and a value from 0.7 is generally considered to represent an acceptable scale (Wittwer, 2014).

(3) The index used to measure the sampling adequacy is Kaiser-Meyer-Olkin (KMO) index (Field, 2009). The KMO statistic varies between 0 and 1. Hutcheson \& Sofroniou (1999) defined values between 0.50.7 as mediocre, values between 0.7-0.8 as good, values between 0.8-0.9 as great and values above 0.9 as superb.

\section{Step 2. Factor extraction method.}

The main aim of this step is to simplify the dataset structure into a reduced number of latent 
factors or components. Based on the sample sizes and the convergence of the Scree plot (Cattell, 1966) and Kaiser's criterion (Yeomans \& Golder, 1982), six factors were identified at the Ilford and Kamppi interchanges, and eight components were obtained from the analysis of the Moncloa interchange. The explained cumulative variance of the factors accounted for more than $60 \%$ in the three case studies, which means that the underlying structures can be considered correct in all cases.

\section{Step 3. Rotational method}

This step discriminates between factors in order to ensure a more reliable and correct interpretation of the loading of the variables on each one. There are two types of rotation: orthogonal rotation and oblique rotation. The main difference is that orthogonal rotation ensures that latent factors are uncorrelated while the oblique rotation assumes their correlation (Field, 2009). It should be stressed that orthogonal rotation reveals the order of importance of the extracted factors according to the percentage of variance, whereas oblique rotation does not.

Appendix A presents the detailed results and the factor loadings of each observed variable in all cases after rotation. Firstly, orthogonal rotation method was applied. However, the correlation matrices ${ }^{1}$ indicated that the factors were interrelated to some degree in all case studies. As a result, orthogonal rotation method was dismissed and the oblique rotation was therefore selected as the appropriate method. Interestingly, it should be noting that the same underlying structures were obtained for both rotational methods in all cases studies (see Table A.1, Table A.2 and Table A.3), which highlights their robustness. Finally, the reliability of the internal consistency of each factor obtained from the oblique rotation was checked (the Cronbach's alpha of each factor was greater than 0.7 in all cases).

\section{Step 4. Interpretation}

The results of the PCA must reflect theoretical and conceptual assumptions. Loadings with an absolute value of over 0.3 can be considered important, although the sample size also has an influence (larger sample sizes imply statistically meaningful smaller loadings) (Field, 2009). The number of factors is considered correct in human sciences when the underlying structure explains at least 50-60\% of the variance (Wittwer, 2014; Streiner, 1994).

\section{Interpretation and discussion of results}

The quality of both the infrastructure (building, facilities and so on) and services (information provided and so on) perceived by the users of a transport interchange usually depends on the context of the interchange (Hine \& Scott, 2000; Redman, Friman, Gärling, \& Hartig, 2013; Abreu e Silva \& Bazrafshan, 2013; Harmer et al., 2014). Some of the issues that can directly influence the users' perception include the main modes of transport involved,

\footnotetext{
${ }^{1}$ The component correlation matrix and the theoretical and conceptual assumptions are a guide to whether it is reasonable to assume independence between factors. This matrix, the final output, contains the correlation coefficients between factors (Field, 2009).
} 
location of the infrastructure, age of the building, and user profiles and travel patterns.

However, an analysis of the results of this research points to some fundamental elements in all case studies independently of the interchange context. Even though the three transport interchanges are significantly different, they share certain key factors and the observed variables that define each one (i.e. the variables with the highest factor loadings ${ }^{2}$ -see Appendix A). The factors that define an urban transport interchange are 'Information', 'Transfer conditions', 'Safety \& Security', 'Emergency situations', 'Design \& Image', 'Environmental quality', 'Services \& Facilities' and 'Comfort of waiting time'. Table 4 shows these factors and the main observed variables in each case study. It is also worth noting that some components or factors are influenced by different aspects according to the context of the urban interchange. 'Information' and 'Transfer conditions' are clustered in the case of the Ilford Railway Station and 'Environmental quality' is clustered with the 'Safety \& Security' factor in the case of the Kamppi interchange (see Appendix A - Table A.1 and Table A.3).

Table 4: Key factors obtained from the oblique rotation and their main observed variables in each case study

\begin{tabular}{|c|c|c|c|}
\hline \multicolumn{4}{|c|}{ Main observed variables } \\
\hline Key factors & Ilford Railway Station & Moncloa $^{\mathrm{a}}$ & Kamppi \\
\hline \multirow[b]{2}{*}{ Information } & \multirow[b]{3}{*}{ Travel information } & Signposting & \multirow{3}{*}{$\begin{array}{l}\text { Travel information } \\
\text { (displays \& at } \\
\text { interchange) }\end{array}$} \\
\hline & & Travel information & \\
\hline \multirow{3}{*}{$\begin{array}{l}\text { Transfer } \\
\text { conditions }\end{array}$} & & $\begin{array}{l}\text { (at interchange) } \\
\text { Transfer distance }\end{array}$ & \\
\hline & \multirow[t]{2}{*}{$\begin{array}{l}\text { Transport operator } \\
\text { coordination }\end{array}$} & $\begin{array}{l}\text { Transport operator } \\
\text { coordination }\end{array}$ & \multirow[t]{2}{*}{$\begin{array}{l}\text { Distance } \\
\text { (facilities \& transfer) }\end{array}$} \\
\hline & & $\begin{array}{l}\text { Use of time } \\
\text { (at interchange) }\end{array}$ & \\
\hline \multirow{2}{*}{$\begin{array}{l}\text { Safety \& } \\
\text { Security }\end{array}$} & \multirow{2}{*}{$\begin{array}{l}\text { Security in transfer \& } \\
\text { waiting areas } \\
\text { (evening/night) } \\
\text { Security surrounding } \\
\text { area }\end{array}$} & \multirow{2}{*}{$\begin{array}{l}\text { Security in transfer \& } \\
\text { waiting areas } \\
\text { Security surrounding } \\
\text { area }\end{array}$} & $\begin{array}{l}\text { Safety } \\
\text { (inside interchange) } \\
\text { Security in transfer \& }\end{array}$ \\
\hline & & & $\begin{array}{l}\text { Security in transfer \& } \\
\text { waiting areas } \\
\text { Security surrounding } \\
\text { area }\end{array}$ \\
\hline \multirow{2}{*}{$\begin{array}{l}\text { Emergency } \\
\text { situations }\end{array}$} & \multirow{2}{*}{$\begin{array}{l}\text { Emergency exits } \\
\text { (Location \& Signposting) }\end{array}$} & \multirow{2}{*}{$\begin{array}{l}\text { Emergency exits } \\
\text { (Location \& Signposting) }\end{array}$} & $\begin{array}{l}\text { Escalators } \\
\text { (case of fire) }\end{array}$ \\
\hline & & & $\begin{array}{l}\text { Emergency exits } \\
\text { (Location) }\end{array}$ \\
\hline Design \& & Design & Design & Design \\
\hline Image & (External \& Internal) & (External \& Internal) & (External \& Internal) \\
\hline \multirow{2}{*}{$\begin{array}{l}\text { Environmenta } \\
\text { l quality }\end{array}$} & Noise & Air quality & Air quality \\
\hline & Temperature & Noise & Temperature \\
\hline \multirow{2}{*}{$\begin{array}{l}\text { Services \& } \\
\text { Facilities }\end{array}$} & Shops & Shops & \multirow{2}{*}{$\begin{array}{l}\text { Coffee-shops \& } \\
\text { restaurants }\end{array}$} \\
\hline & Coffee-shops \& & Coffee-shops \& & \\
\hline
\end{tabular}

${ }^{2}$ Large factor loadings indicate a significant influence of the variable on the latent factor. Conversely, small factor loadings suggest that the variable is not substantially influenced by this factor (Tyrinopoulos \& Antoniou, 2008). 


\begin{tabular}{llll}
\hline & restaurants & restaurants & \multicolumn{2}{c}{ Shops } \\
\hline \multirow{2}{*}{$\begin{array}{l}\text { Comfort of } \\
\text { waiting time }\end{array}$} & ---- & Telephone signal \& Wi-Fi & ---- \\
& & Travel information \\
displays & \\
\hline
\end{tabular}

Extraction Method: Principal Component Analysis. Rotation Method: Oblimin with Kaiser Normalization. Eigenvalue $>1$.

a Factor 'Comfort of waiting time' was only identified in the Moncloa transport interchange

These factors define an efficient urban transport interchange from two different perspectives, functional and psychological, confirming the previous theoretical and conceptual assumptions based on the literature review. As a consequence, an urban transport interchange should be conceived both as 'a transport node' and 'a place' (see Figure 2). Factors such as 'Information' provision -travel information and signposting- and 'Transfer conditions' -distances and coordination between transport operators- facilitate the use of the interchange 'as a node of transport'. Iseki \& Taylor (2009) concluded that physical conditions such as transfer distances and adequate information can reduce perceived walking times. Conversely, 'Design \& Image', 'Environmental quality' -air quality, noise and temperature- and 'Services \& Facilities' -number and variety of shops and coffeeshops- are more closely related to the users' experience inside an interchange 'as a place'. Iseki \& Taylor (2009) concluded that these factors affect travellers' perceptions of comfort and convenience and thus how they perceive waiting time. Comfort at a transfer terminal is identified as a determining factor in PT users' perceived ease of making a transfer (Guo \& Wilson, 2011). Availability of telephone signal, Wi-Fi and travel information displays can also be oriented to improving the quality of waiting time.

'Safety \& Security' -both inside the interchange and in the surrounding area- are crucial in both approaches, and is directly linked to the overall performance of the interchange. Several authors have noted that personal security at terminals is the most important factor in travellers' decision to use PT (Atkins, 1990).

Finally, 'Safety \& Security', 'Information' and 'Transfer conditions' are identified as the most important factors 3 in all case studies.

\footnotetext{
${ }^{3}$ The variance considered for each factor determines its importance in an orthogonal rotation; that is, when there is not a high correlation between factors or it is not taken into account.
} 


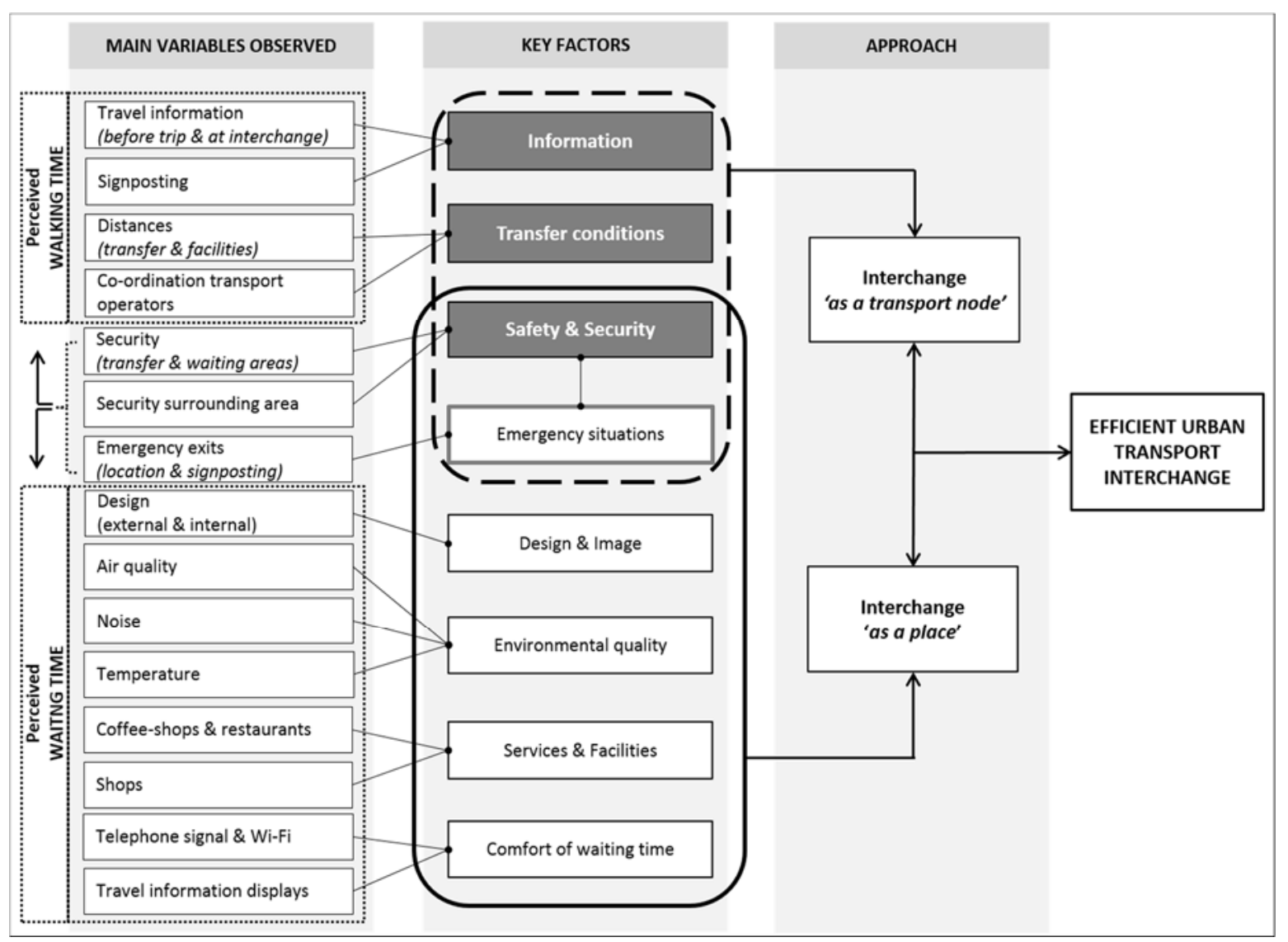

Figure 2: Key factors in a transport interchange

\section{Conclusions and policy recommendations}

Many PT users today need to combine several transport modes or services to reach their final destination, and the inconvenience caused by these transfers has led to a decline in the attractiveness of PT (Guo \& Wilson, 2011). Urban transport interchanges are an everyday experience for users and have become fundamental elements in reducing transfer inconvenience and improving user experience.

This research has identified the key factors from the users' point of view that define an efficient transport interchange -considering them not only 'as nodes' within the transport network, but also 'as places'-, and the most relevant elements and aspects in both approaches.

The results highlight common key factors and attributes in all the case studies, despite significant differences in the features and context of each interchange. General guidelines can be extracted in order to improve the design, operation and management of an urban transport interchange. Since travellers make decisions based on perceived walking and waiting times, it is crucial to reduce the inconvenience of transfers in order to increase the attractiveness of PT. An efficient urban transport interchange should fulfil four essential principles under the dual approach described above:

'As a transport node'

- Reducing waiting time. Transfer distances and co-ordination between operators are crucial. 
- Making it easier to use the interchange and reducing the users' stress levels. Travel information and signposting are the most important aspects here.

'As a place'

- Making the stay more comfortable. Fundamental aspects are external and internal design, air quality, temperature and noise, information displays.

- Improving the use of time in the interchange. Services \& facilities and the availability of a telephone signal and Wi-Fi could help achieve this purpose.

Finally, Safety \& Security are psychological features that are indispensable to users and are directly linked to the overall performance of the interchange. It is particularly important to pay special attention to security aspects in transfer and waiting areas and in the surroundings, and the emergency exits should be clearly located and signposted, and perfectly identified.

In conclusion, current urban transport interchanges can host other type of activities and act not only as transport nodes, but also as meeting places within cities. As noted by Scott (2003), urban transport interchanges are therefore key features for the future development of cities.

\section{Acknowledgements}

The authors acknowledge the financial support of the European Commission which enabled this research into the data collected in the City-HUB project of the EU $7^{\text {th }}$ Framework Programme. We would also like to thank Ms Prudence Brooke-Turner for her revision of the English manuscript. 


\section{APPENDIX A. Results of the PCA: factor loadings}

\begin{tabular}{|c|c|c|c|c|c|}
\hline \multicolumn{2}{|c|}{ Rotation Method } & \multicolumn{2}{|c|}{ Orthogonal } & \multicolumn{2}{|c|}{ Oblique } \\
\hline Factor & Observed variables & $\begin{array}{r}\text { Factor } \\
\text { loadings }\end{array}$ & $\begin{array}{r}\text { Variance } \\
\text { explained } \\
(\%)\end{array}$ & $\begin{array}{r}\text { Factor } \\
\text { loadings }\end{array}$ & $\begin{array}{r}\text { Cronbach's } \\
\text { alpha }\end{array}$ \\
\hline \multirow{12}{*}{$\begin{array}{l}\text { Information \& } \\
\text { Transfer } \\
\text { conditions }\end{array}$} & Travel information before trip & 0.812 & 19.354 & 0.878 & \multirow{12}{*}{0.938} \\
\hline & Travel information displays & 0.750 & & 0.764 & \\
\hline & $\begin{array}{l}\text { Travel information at } \\
\text { interchange }\end{array}$ & 0.747 & & 0.762 & \\
\hline & $\begin{array}{l}\text { Co-ordination transport } \\
\text { operators }\end{array}$ & 0.721 & & 0.703 & \\
\hline & Transfer distance & 0.718 & & 0.678 & \\
\hline & Use of time at interchange & 0.673 & & 0.641 & \\
\hline & Signposting to transfer & 0.644 & & 0.613 & \\
\hline & $\begin{array}{l}\text { Signposting facilities and } \\
\text { services }\end{array}$ & 0.638 & & 0.565 & \\
\hline & Ticket purchase & 0.618 & & 0.550 & \\
\hline & Information provided by staff & 0.621 & & 0.546 & \\
\hline & Distance between facilities & 0.510 & & 0.424 & \\
\hline & Accessibility & 0.641 & & 0.409 & \\
\hline \multirow{5}{*}{$\begin{array}{l}\text { Design \& } \\
\text { Image }\end{array}$} & External design & 0.724 & 10.486 & 0.643 & \multirow{5}{*}{0.857} \\
\hline & Internal design & 0.728 & & 0.628 & \\
\hline & $\begin{array}{l}\text { Number of elevators, } \\
\text { escalators }\end{array}$ & 0.630 & & 0.576 & \\
\hline & Surrounding area is pleasant & 0.654 & & 0.560 & \\
\hline & Movement (crowding) & 0.536 & & 0.428 & \\
\hline \multirow[t]{6}{*}{$\begin{array}{l}\text { Safety \& } \\
\text { Security }\end{array}$} & $\begin{array}{l}\text { Security in transfer and } \\
\text { waiting areas (evening/night) }\end{array}$ & 0.752 & 12.316 & 0.814 & \multirow[t]{6}{*}{0.911} \\
\hline & Security surrounding area & 0.747 & & 0.812 & \\
\hline & Safety (inside interchange) & 0.738 & & 0.771 & \\
\hline & $\begin{array}{l}\text { Security in transfer and } \\
\text { waiting areas (day) }\end{array}$ & 0.713 & & 0.750 & \\
\hline & $\begin{array}{l}\text { Safety getting on / off the } \\
\text { transport mode }\end{array}$ & 0.692 & & 0.700 & \\
\hline & Lighting & 0.587 & & 0.555 & \\
\hline \multirow{3}{*}{$\begin{array}{l}\text { Emergency } \\
\text { situations }\end{array}$} & Signposting to emergency exits & 0.787 & 7.410 & 0.851 & \multirow{3}{*}{0.940} \\
\hline & $\begin{array}{l}\text { Location of emergency exits } \\
\text { (emergency event) }\end{array}$ & 0.773 & & 0.834 & \\
\hline & $\begin{array}{l}\text { Real time information to } \\
\text { improve sense of security }\end{array}$ & 0.737 & & 0.788 & \\
\hline \multirow{5}{*}{$\begin{array}{l}\text { Services \& } \\
\text { Facilities }\end{array}$} & Shops & 0.798 & 9.473 & 0.846 & \multirow{5}{*}{0.855} \\
\hline & Coffee-shops and restaurants & 0.791 & & 0.833 & \\
\hline & Cash machines & 0.745 & & 0.783 & \\
\hline & Telephone signal and WI-FI & 0.479 & & 0.447 & \\
\hline & Comfort (information screens) & 0.418 & & 0.342 & \\
\hline \multirow{5}{*}{$\begin{array}{l}\text { Environmental } \\
\text { quality }\end{array}$} & Noise & 0.780 & 9.585 & 0.867 & \multirow{5}{*}{0.864} \\
\hline & Temperature & 0.679 & & 0.727 & \\
\hline & Cleaning (generally) & 0.655 & & 0.700 & \\
\hline & Air quality & 0.624 & & 0.665 & \\
\hline & Seating & 0.402 & & 0.355 & \\
\hline \multicolumn{2}{|c|}{ Explained cumulative variance (\%) } & \multicolumn{4}{|r|}{68.625} \\
\hline
\end{tabular}

Table A.1: Summary of the exploratory PCA of the travellers' satisfaction survey at Ilford

Extraction Method: Principal Component Analysis. Rotation Methods: Varimax \& Oblimin with Kaiser Normalization. Eigenvalue $>1$. 
Table A.2: Summary of exploratory PCA of the travellers' satisfaction survey at Moncloa

\begin{tabular}{|c|c|c|c|c|c|}
\hline \multirow[b]{2}{*}{ Factor } & \multirow[b]{2}{*}{ Observed variables } & \multicolumn{2}{|c|}{ Orthogonal } & \multicolumn{2}{|c|}{ Oblique } \\
\hline & & $\begin{array}{r}\text { Factor } \\
\text { loadings }\end{array}$ & $\begin{array}{r}\text { Variance } \\
\text { explained } \\
(\%)\end{array}$ & $\begin{array}{r}\text { Factor } \\
\text { loadings }\end{array}$ & $\begin{array}{r}\text { Cronbach's } \\
\text { alpha }\end{array}$ \\
\hline \multirow[t]{7}{*}{ Information } & $\begin{array}{l}\text { Signposting facilities and } \\
\text { services }\end{array}$ & 0.692 & \multirow[t]{7}{*}{10.038} & 0.671 & \multirow[t]{7}{*}{0.814} \\
\hline & Signposting to transfer & 0.694 & & 0.656 & \\
\hline & $\begin{array}{l}\text { Travel information at } \\
\text { interchange }\end{array}$ & 0.634 & & 0.577 & \\
\hline & Ticket purchase & 0.550 & & 0.510 & \\
\hline & Information provided by staff & 0.501 & & 0.419 & \\
\hline & Travel information before trip & 0.485 & & 0.411 & \\
\hline & Accessibility & 0.447 & & 0.351 & \\
\hline \multirow{5}{*}{$\begin{array}{l}\text { Transfer } \\
\text { conditions }\end{array}$} & Transfer distance & 0.736 & \multirow[t]{5}{*}{7.790} & 0.798 & \multirow[t]{5}{*}{0.797} \\
\hline & $\begin{array}{l}\text { Co-ordination transport } \\
\text { operators }\end{array}$ & 0.718 & & 0.755 & \\
\hline & Use of time at interchange & 0.701 & & 0.741 & \\
\hline & Distance between facilities & 0.592 & & 0.602 & \\
\hline & Movement (crowding) & 0.438 & & 0.412 & \\
\hline \multirow{3}{*}{$\begin{array}{l}\text { Design \& } \\
\text { Image }\end{array}$} & External design & 0.724 & \multirow[t]{3}{*}{6.831} & 0.723 & \multirow[t]{3}{*}{0.835} \\
\hline & Surrounding area is pleasant & 0.697 & & 0.700 & \\
\hline & Internal design & 0.709 & & 0.688 & \\
\hline \multirow[t]{6}{*}{$\begin{array}{l}\text { Safety \& } \\
\text { Security }\end{array}$} & $\begin{array}{l}\text { Security in transfer and } \\
\text { waiting areas (evening/night) }\end{array}$ & 0.794 & \multirow[t]{6}{*}{11.013} & 0.831 & \multirow[t]{6}{*}{0.881} \\
\hline & $\begin{array}{l}\text { Security in transfer and } \\
\text { waiting areas (day) }\end{array}$ & 0.790 & & 0.826 & \\
\hline & Security surrounding area & 0.740 & & 0.784 & \\
\hline & Lighting & 0.667 & & 0.669 & \\
\hline & Safety (inside interchange) & 0.618 & & 0.638 & \\
\hline & $\begin{array}{l}\text { Safety getting on and off the } \\
\text { transport mode }\end{array}$ & 0.641 & & 0.607 & \\
\hline \multirow[t]{4}{*}{$\begin{array}{l}\text { Emergency } \\
\text { situations }\end{array}$} & $\begin{array}{l}\text { Location of emergency exits } \\
\text { (emergency event) }\end{array}$ & 0.806 & \multirow[t]{4}{*}{8.583} & 0.891 & \multirow[t]{4}{*}{0.903} \\
\hline & $\begin{array}{l}\text { Signposting to emergency } \\
\text { exits }\end{array}$ & 0.783 & & 0.862 & \\
\hline & $\begin{array}{l}\text { Location of escalators in the } \\
\text { event of an emergency }\end{array}$ & 0.756 & & 0.831 & \\
\hline & $\begin{array}{l}\text { Real time information to } \\
\text { improve sense of security }\end{array}$ & 0.660 & & 0.683 & \\
\hline \multirow{3}{*}{$\begin{array}{l}\text { Services \& } \\
\text { Facilities }\end{array}$} & Shops & 0.798 & \multirow[t]{3}{*}{6.003} & 0.822 & \multirow[t]{3}{*}{0.757} \\
\hline & Coffee-shops and restaurants & 0.792 & & 0.814 & \\
\hline & Cash machines & 0.502 & & 0.488 & \\
\hline \multirow{4}{*}{$\begin{array}{l}\text { Environmen } \\
\text { tal quality }\end{array}$} & Air quality & 0.740 & \multirow[t]{4}{*}{7.464} & 0.789 & \multirow[t]{4}{*}{0.793} \\
\hline & Noise & 0.709 & & 0.750 & \\
\hline & Temperature & 0.668 & & 0.684 & \\
\hline & Cleaning (generally) & 0.565 & & 0.548 & \\
\hline \multirow{4}{*}{$\begin{array}{l}\text { Comfort of } \\
\text { waiting time }\end{array}$} & Telephone signal and WI-FI & 0.630 & \multirow[t]{4}{*}{5.843} & 0.603 & 0.707 \\
\hline & Travel information displays & 0.564 & & 0.539 & \\
\hline & Comfort (information screens) & 0.566 & & 0.496 & \\
\hline & Seating & 0.498 & & 0.436 & \\
\hline Explained $\mathrm{cu}$ & nulative variance $(\%)$ & & & & 63.566 \\
\hline
\end{tabular}


Table A.3: Summary of exploratory PCA of the travellers' satisfaction survey at Kamppi transport

\begin{tabular}{|c|c|c|c|c|c|}
\hline \multicolumn{2}{|c|}{ Rotation Method } & \multicolumn{2}{|c|}{ Orthogonal } & \multicolumn{2}{|c|}{ Oblique } \\
\hline Factor & Observed variables & $\begin{array}{r}\text { Factor } \\
\text { loadings }\end{array}$ & $\begin{array}{r}\text { Variance } \\
\text { explained } \\
(\%)\end{array}$ & $\begin{array}{r}\text { Factor } \\
\text { loadings }\end{array}$ & $\begin{array}{r}\text { Cronbach's } \\
\text { alpha }\end{array}$ \\
\hline \multirow[t]{4}{*}{ Information } & Travel information displays & 0.739 & 10.319 & 0.801 & 0.768 \\
\hline & $\begin{array}{l}\text { Travel information at } \\
\text { interchange }\end{array}$ & 0.745 & & 0.784 & \\
\hline & Travel information before trip & 0.743 & & 0.778 & \\
\hline & $\begin{array}{l}\text { Co-ordination transport } \\
\text { operators }\end{array}$ & 0.364 & & 0.297 & \\
\hline \multirow{10}{*}{$\begin{array}{l}\text { Transfer } \\
\text { conditions }\end{array}$} & Distance between facilities & 0.679 & 17.165 & 0.747 & 0.877 \\
\hline & Use of time at interchange & 0.621 & & 0.638 & \\
\hline & Transfer distance & 0.602 & & 0.626 & \\
\hline & Movement (crowding) & 0.552 & & 0.550 & \\
\hline & Signposting to transfer & 0.556 & & 0.531 & \\
\hline & $\begin{array}{l}\text { Signposting facilities and } \\
\text { services }\end{array}$ & 0.521 & & 0.502 & \\
\hline & $\begin{array}{l}\text { Number of elevators, } \\
\text { escalators }\end{array}$ & 0.454 & & 0.425 & \\
\hline & Ticket purchase & 0.466 & & 0.404 & \\
\hline & Accessibility & 0.421 & & 0.369 & \\
\hline & Information provided by staff & 0.405 & & 0.338 & \\
\hline \multirow{4}{*}{$\begin{array}{l}\text { Design \& } \\
\text { Image }\end{array}$} & External design & 0.818 & 7.705 & 0.856 & 0.801 \\
\hline & Internal design & 0.806 & & 0.837 & \\
\hline & Surrounding area is pleasant & 0.663 & & 0.669 & \\
\hline & Seating & 0.346 & & 0.308 & \\
\hline \multirow{11}{*}{$\begin{array}{l}\text { Safety \& } \\
\text { Security and } \\
\text { Environment } \\
\text { al quality }\end{array}$} & Safety (inside interchange) & 0.814 & 10.144 & 0.829 & 0.918 \\
\hline & $\begin{array}{l}\text { Security in transfer and } \\
\text { waiting areas (evening/night) }\end{array}$ & 0.728 & & 0.745 & \\
\hline & $\begin{array}{l}\text { Security in transfer and } \\
\text { waiting areas (day) }\end{array}$ & 0.748 & & 0.729 & \\
\hline & Security surrounding area & 0.684 & & 0.707 & \\
\hline & $\begin{array}{l}\text { Safety getting on and off the } \\
\text { transport mode }\end{array}$ & 0.680 & & 0.636 & \\
\hline & Lighting & 0.656 & & 0.625 & \\
\hline & Air quality & 0.618 & & 0.568 & \\
\hline & Temperature & 0.616 & & 0.557 & \\
\hline & Cleaning (generally) & 0.602 & & 0.541 & \\
\hline & Noise & 0.598 & & 0.539 & \\
\hline & Comfort (information screens) & 0.496 & & 0.412 & \\
\hline \multirow[t]{4}{*}{$\begin{array}{l}\text { Emergency } \\
\text { situations }\end{array}$} & $\begin{array}{l}\text { Location of escalators in the } \\
\text { event of an emergency }\end{array}$ & 0.782 & 7.456 & 0.767 & 0.908 \\
\hline & $\begin{array}{l}\text { Location of emergency exits } \\
\text { (emergency event) }\end{array}$ & 0.789 & & 0.761 & \\
\hline & $\begin{array}{l}\text { Signposting to emergency } \\
\text { exits }\end{array}$ & 0.751 & & 0.715 & \\
\hline & $\begin{array}{l}\text { Real time information to } \\
\text { improve sense of security }\end{array}$ & 0.622 & & 0.548 & \\
\hline \multirow{4}{*}{$\begin{array}{l}\text { Services \& } \\
\text { Facilities }\end{array}$} & Coffee-shops and restaurants & 0.816 & 8.217 & 0.816 & 0.747 \\
\hline & Shops & 0.807 & & 0.807 & \\
\hline & Cash machines & 0.545 & & 0.509 & \\
\hline & Telephone signal and WI-FI & 0.369 & & 0.334 & \\
\hline
\end{tabular}

Extraction Method: Principal Component Analysis. Rotation Methods: Varimax \& Oblimin with Kaiser Normalization. Eigenvalue $>1$ 


\section{References}

Abreu e Silva, J., \& Bazrafshan, H. (2013). User Satisfaction of Intermodal Transfer Facilities in Lisbon, Portugal: Analysis with Structural Equations Modeling. Transportation Research Record: Journal of the Transportation Research Board, 2350(1), 102-110. http://doi.org/10.3141/2350-12

Atkins, S. T. (1990). Personal security as a transport issue: a state-of-the-art review. Transport Reviews, 10(2), 111-125. http://doi.org/10.1080/01441649008716748

Banister, D. (2011). The trilogy of distance, speed and time. Journal of Transport Geography, 19(4), 950-959. http://doi.org/10.1016/j.jtrangeo.2010.12.004

Bertolini, L., \& Spit, T. (1998). Cities on Rails: The Redevelopment of Railway Stations and their Surroundings. Taylor \& Francis.

Cattell, R. B. (1966). The scree test for the number of factors. Multivariate Behavioral Research, 1(2), 245-276. http://doi.org/10.1207/s15327906mbr0102_10

COM. (2006). COMMUNICATION FROM THE COMMISSION TO THE COUNCIL AND THE EUROPEAN PARLIAMENT. Keep Europe moving - Sustainable mobility for our continent Mid-term review of the European Commission's 2001 Transport White Paper. Luxembourg: Office for Official Publications of the European Communities.

COM. (2007). 551 final, Green Paper: Towards a new culture for urban mobility. Brussels.

Comendador, J., López-Lambas, M. E., \& Monzon, A. (2014). Urban built environment analysis: evidence from a mobility survey in Madrid (pp. 1-16). Presented at the XI Congreso de Ingeniería del Transporte, CIT 2014, Santander. España. Retrieved from http://www.cit2014.unican.es/index.php?lang=ES

Committee on Intermodal Transfer Facilities, Transportation Research Board. (1974). Intermodal Transfer Facilities Research Needs. In Transportation Research Record. Retrieved from http://pubsindex.trb.org/view/1974/C/140551

Comrey, A. L., \& Lee, H. B. (1992). A first course in factor analysis. L. Erlbaum Associates.

Costello, A., \& Osborne, J. (2005). Best practices in exploratory factor analysis: Four recommendations for getting the most from your analysis. Practical Assessment, Research \& Evaluation, 10(7), 173-178.

Debnath, A. K., Chin, H. C., Haque, M. M., \& Yuen, B. (2014). A methodological framework for benchmarking smart transport cities. Cities, 37, 47-56. http://doi.org/10.1016/j.cities.2013.11.004

De Oña, R. (2013). Analysis of service quality in public transportation using decision trees (Ph.D. Thesis). Universidad Politecnica de Granada, Spain.

Desiderio, N. (2004). Requirements of Users and Operators on the Design and Operation of Intermodal Interchanges. Technishe Universitat Darmstadt, Fachgebiet Verkehrsplanung und Verkehrstechnik. Retrieved from http://www.verkehr.tudarmstadt.de/media/verkehr/fgvv/for/publik/S007.pdf

Durmisevic, S., \& Sariyildiz, S. (2001). A systematic quality assessment of underground spaces - public transport stations. Cities, 18(1), 13-23. http://doi.org/10.1016/S02642751(00)00050-0

Edwards, B. (2011). Sustainability and the Design of Transport Interchanges. Taylor \& Francis.

Field, A. P. (2009). Discovering Statistics Using SPSS: (and Sex, Drugs and Rock'n'roll) (Third Edition). SAGE.

Friman, M. (2010). Affective dimensions of the waiting experience. Transportation Research Part F: Traffic Psychology and Behaviour, 13(3), 197-205. http://doi.org/10.1016/j.trf.2010.04.006 
Garmendia, M., Ribalaygua, C., \& Ureña, J. M. (2012). High speed rail: implication for cities. Cities, 29, Supplement 2, S26-S31. http://doi.org/10.1016/j.cities.2012.06.005

Guo, Z., \& Wilson, N. H. M. (2011). Assessing the cost of transfer inconvenience in public transport systems: A case study of the London Underground. Transportation Research Part A: Policy and Practice, 45(2), 91-104. http://doi.org/10.1016/j.tra.2010.11.002

Harmer, C., Millard, K., Palmer, D., Ubbels, B., Monzon, A., \& Hernandez, S. (2014). What makes a successful interchange? Presented at the TRA2014 Transport Research Arena 2014. Transport Solutions: from Research to Deployment - Innovate Mobility, Mobilise Innovation, Paris, France.

Heilig, G. K. (2012). World Urbanization Prospects, the 2011 Revision (Report). New York: United Nations, Department of Economic and Social Affairs (DESA), Population Division, Population Estimates and Projections Section. Retrieved from http://www.un.org/en/development/desa/publications/world-urbanization-prospects-the2011-revision.html

Hernandez, S., Monzon, A., \& De Oña, R. (2015). Urban transport interchanges: a methodology for evaluating perceived quality. Accepted for publication in Transportation Research Part A: Policy and Practice.

Hine, J., \& Scott, J. (2000). Seamless, accessible travel: users' views of the public transport journey and interchange. Transport Policy, 7(3), 217-226. http://doi.org/10.1016/S0967070X(00)00022-6

Hutcheson, G. D., \& Sofroniou, N. (1999). The Multivariate Social Scientist: Introductory Statistics Using Generalized Linear Models (1 edition). London; Thousand Oaks, Calif: SAGE Publications Ltd.

Iseki, H., \& Taylor, B. D. (2009). Not All Transfers Are Created Equal: Towards a Framework Relating Transfer Connectivity to Travel Behaviour. Transport Reviews, 29(6), 777-800. http://doi.org/10.1080/01441640902811304

Iseki, H., \& Taylor, B. D. (2010). Style versus Service? An Analysis of User Perceptions of Transit Stops and Stations. Journal of Public Transportation, 13(3), 23-48.

Jackson, D. A. (1993). Stopping Rules in Principal Components Analysis: A Comparison of Heuristical and Statistical Approaches. Ecology, 74(8), 2204-2214. http://doi.org/10.2307/1939574

Liu, R., Pendyala, R., \& Polzin, S. (1997). Assessment of Intermodal Transfer Penalties Using Stated Preference Data. Transportation Research Record: Journal of the Transportation Research Board, 1607, 74-80. http://doi.org/10.3141/1607-11

Li, Y. (2013). Multimodal interchange to facilitate seamless journeys. Presented at the 17th IRF World Meeting \& Exhibition, Riyadh, Saudi Arabia. Retrieved from http://irf2013.conferencespot.org/55505-irf-e-1.425157/t-002-1.426065/ts5-8-11.426470/0259-000394-1.426474

Neirotti, P., De Marco, A., Cagliano, A. C., Mangano, G., \& Scorrano, F. (2014). Current trends in Smart City initiatives: Some stylised facts. Cities, 38, 25-36. http://doi.org/10.1016/j.cities.2013.12.010

Peek, G.-J., \& van Hagen, M. (2002). Creating Synergy In and Around Stations: Three Strategies for Adding Value. Transportation Research Record: Journal of the Transportation Research Board, 1793(1), 1-6. http://doi.org/10.3141/1793-01

PIRATE. (1999). Promoting Interchange Rationale, Accessibility and Transfer Efficiency (Final Report). Sheffield: Project funded by the European Commission under the Transport RTD programme of the 4th framework. 
Pitsiava-Latinopoulou, M., \& Iordanopoulos, P. (2012). Intermodal Passengers Terminals: Design Standards for Better Level of Service. Procedia - Social and Behavioral Sciences, 48, 3297-3306. http://doi.org/10.1016/j.sbspro.2012.06.1295

PORTAL. (2003). Integrated transport chains. Transport Teaching Material. European Comission and Research for Sustainable Mobility. Retrieved from http://www.euportal.net/material/downloadarea/ktlc_wm_en.pdf

Redman, L., Friman, M., Gärling, T., \& Hartig, T. (2013). Quality attributes of public transport that attract car users: A research review. Transport Policy, 25, 119-127. http://doi.org/10.1016/j.tranpol.2012.11.005

Scott, F. (2003). InterchangeABLE. London: Helen Hamlyn Centre, Royal College of Art.

Station User Panel. (2011). Railway Station Useability Principles. Melbourne, Australia: Department of Transport, Planning and Local Infrastructure, Victorian Government. Retrieved from http://www.dtpli.vic.gov.au/transport/about-transport-in-victoria/stationuser-panel

Stern, R. (1996). Passenger Transfer System Review. Transportation Research Board.

Streiner, D. L. (1994). Figuring out factors: the use and misuse of factor analysis. Canadian Journal of Psychiatry. Revue Canadienne De Psychiatrie, 39(3), 135-140.

Terzis, G., \& Last, A. (2000). GUIDE - "Urban Interchanges - A Good Practice Guide” (Final Report). Retrieved from http://www.transportresearch.info/Upload/Documents/200310/guide.pdf

Tyrinopoulos, Y., \& Antoniou, C. (2008). Public transit user satisfaction: Variability and policy implications. Transport Policy, 15(4), 260-272. http://doi.org/10.1016/j.tranpol.2008.06.002

van Hagen, M. (2011). Waiting experience at train stations (Ph.D. Thesis). Twenty University, The Netherlands.

Wittwer, R. (2014). Cluster-analytical-creation of a typology of young adults' travel behavior in Germany. Presented at the XI Congreso de Ingeniería del Transporte, CIT 2014, Santander. España.

Yeomans, K. A., \& Golder, P. A. (1982). The Guttman-Kaiser Criterion as a Predictor of the Number of Common Factors. Journal of the Royal Statistical Society. Series D (The Statistician), 31(3), 221-229. http://doi.org/10.2307/2987988 